\title{
HAL HAL YANG HARUS DIHINDARI DALAM PENGAJUAN HAK PATEN
}

\section{Tio Fernandes}

155100075

Fakultas Komputer, 448757212

Tiofernandes.student@umitra.ac.id

\begin{abstract}
Paten adalah hak khusus yang diberikan Negara kepada penemu atas hasil penemuannya di bidang teknologi, untuk jangka waktu tertentu melaksanakan sendiri penemuannya tersebut atau memberikan persetujuannya kepada orang lain untuk melaksanakannya (Pasal 1 ayat 1 UU tentang Paten).

Yang harus dihindari sebelum permintaan Paten diajukan adalah pengungkapan atau mempublikasikan secara umum hasil penelitian atau penemuan dalam jangka waktu lebih dari 6 (enam) bulan sebelum permintaan paten diajukan. Pengungkapan suatu hasil penemuan dan atau penelitian dapat terjadi dalam 3 (tiga) cara yaitu; Melalui penguraian teknik dengan tulisan yang dipublikasikan, Melalui penguraian produk dan atau cara penggunaannya di depan umum, Melalui pameran produk, dapat berupa suatu pameran internasional di Indonesia atau di luar negeri yang resmi atau diakui sebagai resmi atau berupa suatu pameran nasional di Indonesia yang resmi atau diakui sebagai resmi.

Ada 2 macam sistem pendaftaran paten dalam rangka perlindungan hukum, yaitu; Sistem First to File adalah suatu sistem yang memberikan hak paten bagi mereka yang mendaftar pertama atas invensi baru sesuai dengan persyaratan. Sistem First to Invent adalah suatu system yang memberikan hak paten bagi mereka yang menemukan inovasi pertama kali sesuai dengan persyaratan yang telah ditentukan.
\end{abstract}

Kata Kunci : Paten dan Sistem 


\section{A. INTRODUCTION}

Pemegang paten adalah inventor sebagai pemilik paten atau pihak yang menerima hak tersebut dari pemilik paten atau pihak lain yang menerima lebih lanjut hak tersebut, yang terdaftar dalam Daftar Umum Paten

Yang harus dihindari sebelum permintaan Paten diajukan adalah pengungkapan atau mempublikasikan secara umum hasil penelitian atau penemuan dalam jangka waktu lebih dari 6 (enam) bulan sebelum permintaan paten diajukan. Pengungkapan suatu hasil penemuan dan atau penelitian dapat terjadi dalam 3 (tiga) cara yaitu; Melalui penguraian teknik dengan tulisan yang dipublikasikan, Melalui penguraian produk dan atau cara penggunaannya di depan umum, Melalui pameran produk, dapat berupa suatu pameran internasional di
Indonesia atau di luar negeri yang resmi atau diakui sebagai resmi atau berupa suatu pameran nasional di Indonesia yang resmi atau diakui sebagai resmi.

Ada 2 macam sistem pendaftaran paten dalam rangka perlindungan hukum, yaitu; Sistem First to File adalah suatu sistem yang memberikan hak paten bagi mereka yang mendaftar pertama atas invensi baru sesuai dengan persyaratan. Sistem First to Invent adalah suatu system yang memberikan hak paten bagi mereka yang menemukan inovasi pertama kali sesuai dengan persyaratan yang telah ditentukan.

- Ruang Lingkup Paten Di Indonesia syarat untuk suatu invensi yang dapat dipatenkan adalah

a. Baru atau novelty; baru berarti belum pernah diungkapkan sebelumnya. 
Teknologi dalam invensi tidak sama dengan teknologi yang sudah pernah terungkap sebelumnya.

Untuk memastikan bahwa teknologi yang diteliti belum dipatenkan oleh pihak lain dan layak untuk dipatenkan, inventor sebelum memohon pendaftaran dapat melakukan penelususran dokumen paten, baik melalui internet atai library. b. Mengandung langkah inventif artinya; belum dapat diduga sebelumnya oleh pakar dibidangnya.

c. Dapat diterapkan dalam dunia industry artinya; bukanteori semata. Obyeknya baik paten proses atau paten produk dan alat akan diproduks dalam jumlah besar dan diperjualbelikan, serta haknya dapat dialihkan ke dunia bisnis melalui perjanjian lisensi, atau yang lain.

Sistem Pendaftaran

Paten Ada dua (2) system pendaftaran paten, yaitu: a. Sistem first to file adalah suatu system yang memberikan hak paten bagi mereka yang mendaftar pertama atas invensi baru sesuai dengan persyaratan. b. Sistem first to invent adalah suatu system yang memberikan hak paten bagi mereka yang menemukan inovasi pertama kali sesuai dengan persyaratan yang telah ditentukan. Dokumen-dokumen yang diperlukan untuk pendaftaran permohonan paten adalah sebagai berikut:

a. Formulir yang telah diisi. b. Spesifikasi permohonan paten 3 rangkap. c. Surat kuasa, jika diajukan melalui kuasa hokum. d. Surat pernyataan untuk diberi paten.

. Hal-hal Dihindari Sebelum Mengajukan Paten Yang harus dihindari sebelum permintaan paten diajukan adalah pengungkapan atau mempublikasikan secara umum hasil penelitian atau penemuan 
dalam jangka waktu 6 (enam)

bulan sebelum permintaan

paten diajukan. Pengugkapan

suatu hasil penelitian atau penemuan dapat terjadi dalam

3 cara:

a. Melalui penguraian teknik dengan tulisa yang dipublikasikan.

b. Melalui penguraian produk dan atau cara penggunanya di depan umum.

c. Melalui pameran produk, dapat berupa suatu pameran internasional atau nasional di Indonesia atau di luar negeri yang resmi atau diakui sebagai resmi.

Yang Harus Dilakukan

Sebelum Mengajukan Paten

a. Melakukan penelususran (searching) informasi paten di beberapa website, antara lain:

b. Melakukan analisa, dan men-cheek apakah ada cirri khusus dari invensi yang akan diajukan untuk mendapat perlindungan hak paten dibandingkan dengan invensi terdahulu, yang masih berlaku hak patennya.

Peraturan perundangundangan apakah yang mengatur tentang paten?

- Undang-undang No. 14 Tahun 2001 tentang Paten (UUP);

- Undang-undang No.7 Tahun 1994 tentang Agreement Establishing the World Trade Organization (persetujuan Pembentukan Organisasi Perdagangan Dunia);

- Keputusan Presiden No.16 Tahun 1997 tentang Pengesahan PCT and Regulationsunder the PCT;

- Keputusan Presiden No.15 Tahun 1997 tentang Pengesahan Paris Convention forthe Protection of Industrial Property;

- Peraturan Pemerintah No. 34 Tahun 1991 tentang Tata Cara Permintaan Paten;

- PeraturanPemerintah No.11 Tahu n 1991 tentang Bentuk dan Isi Surat Paten;

- Keputusan Menkeh No. M.O1HC.O2.10 Tahun 1991 tentang Paten Sederhana;

- Keputusan Menkeh No. M.O2HC.O1.10 Tahun 1991 tentang 
Penyelenggaraan Pengumuman

Paten;

- Keputusan Menkeh No. N.O4HC.O2.10 Tahun 1991 tentang Persyaratan, Jangka Waktu, dan Tata Cara Pembayaran Biaya Paten;

- Keputusan Menkeh No. M.O6HC.O2.10 Tahun 1991 tentang Pelaksanaan Pengajuan

Permintaan Paten;

- Keputusan Menkeh No. M.O7HC.O2.10 Tahun 1991 tentang Bentuk dan

SyaratsyaratPermintaan

Pemeriksaan Substantif Paten;

- Keputusan Menkeh No. M.O8HC.O2.10 Tahun 1991 tentang Pencatatan danPermintaan Salinan Dokumen Paten;

- Keputusan Menkeh No. M.O4PR.07.10 Tahun 1996 tentang Sekretariat KomisiBanding Paten;

- Keputusan Menkeh No. M.O1HC.O2.10 Tahun 1991 tentang Tata CaraPengajuan Permintaan Banding Paten.

- Pemegang paten memiliki hak eksklusif untuk melaksanakan paten yang dimilikinya dan melarang orang lain yang tanpa persetujuannya :

1. dalam hal paten produk: membuat, menjual, mengimport, menyewa, menyerahkan memakai, menyediakan untuk dijual atau disewakan atau diserahkan produk yang diberi paten;

2. dalam hal paten proses:menggunakan proses produksi yang diberi paten untuk membuat barang dan tindakan lainnya sebagaimana yang dimaksud dalam huruf a .

- Pemegang paten berhak memberikan lisensi kepada orang lain berdasarkan surat perjanjian lisensi;

- $\quad$ Pemegang paten berhak menggugat ganti rugi melalui pengadilan negeri setempat, kepada siapapun, yang dengan sengaja dan tanpa hak melakukan perbuatan sebagaimana dimaksud dalam butir 1 diatas;

- Pemegang paten berhak menuntut orang yang dengan sengaja dan tanpa hak melanggar hak Pemegang Paten dengan 
melakukan salah satu tindakan sebagaimana yang dimaksud dalam butir 1 di atas.

- Pemegang paten wajib membayar biaya pemeliharaan yang disebut biaya tahunan;

- Pemegang paten wajib melaksanakan patennya di wilayah Negara Republik Indonesia kecuali apabila pelaksanaan paten tersebut secara ekonomi hanya layak bila dibuat dengan skala regional dan ada pengajuan permohonan tertulis dari pemegang paten dengan disertai alasan dan bukti-bukti yang diberikan oleh instansi yang berwenang dan disetujui oleh Ditjen HKI.

\begin{tabular}{|c|c|c|}
\hline \multicolumn{3}{|c|}{ mengajukan } \\
\hline permohonan & paten, & \\
\hline ilakukan & tahap-tahap & \\
\hline
\end{tabular}

1. Melakukan penelusuran. Tahapan ini dimaksudkan untuk mendapatkan informasi tentang teknologi terdahulu dalam bidang invensi yang sama (state of the art) yang memungkinkan ada kaitannya dengan invensi yang akan diajukan. Melalui informasi teknologi terdahulu tersebut maka inventor dapat melihat perbedaan antara invensi yang akan diajukan permohonan patennya dengan teknologi terdahulu;

2. Melakukan analisa. Tahapan ini dimaksudkan untuk menganalisa apakah ada ciri khusus dari invensi yang akan diajukan permohonan patennya dibandingkan dengan invensi terdahulu;

3. Mengambil keputusan. Jika invensi yang dihasilkan tersebut mempunyai ciri teknis dibandingkan dengan teknologi terdahulu, maka invensi tersebut sebaiknya diajukan permohonan patennya. Sebaliknya jika tidak ditemukan ciri khusus, maka invensi tersebut sebaiknya tidak perlu diajukan untuk menghindari kerugian dari biaya 


pengajuan permohonan
paten.

\section{B. CONCLUSION}

Yang harus dihindari sebelum permintaan Paten diajukan adalah pengungkapan atau mempublikasikan secara umum hasil penelitian atau penemuan dalam jangka waktu lebih dari 6 (enam) bulan sebelum permintaan paten diajukan. Pengungkapan suatu hasil penemuan dan atau penelitian dapat terjadi dalam 3 (tiga) cara yaitu; Melalui penguraian teknik dengan tulisan yang dipublikasikan, Melalui penguraian produk dan atau cara penggunaannya di depan umum, Melalui pameran produk, dapat berupa suatu pameran internasional di Indonesia atau di luar negeri yang resmi atau diakui sebagai resmi atau berupa suatu pameran nasional di Indonesia yang resmi atau diakui sebagai resmi.

\begin{abstract}
Ada 2 macam sistem pendaftaran paten dalam rangka perlindungan hukum, yaitu; Sistem First to File adalah suatu sistem yang memberikan hak paten bagi mereka yang mendaftar pertama atas invensi baru sesuai dengan persyaratan. Sistem First to Invent adalah suatu system yang memberikan hak paten bagi mereka yang menemukan inovasi pertama kali sesuai dengan persyaratan yang telah ditentukan.

Di Indonesia syarat untuk suatu invensi yang dapat dipatenkan adalah
\end{abstract}

a. Baru atau novelty; baru berarti belum pernah diungkapkan sebelumnya. Teknologi dalam invensi tidak sama dengan teknologi yang sudah pernah terungkap sebelumnya. Untuk memastikan bahwa teknologi yang diteliti belum dipatenkan oleh pihak lain dan layak untuk dipatenkan, inventor sebelum memohon pendaftaran dapat 


\begin{abstract}
melakukan penelususran dokumen paten, baik melalui internet atai library. b. Mengandung langkah inventif artinya; belum dapat diduga sebelumnya oleh pakar dibidangnya.

c. Dapat diterapkan dalam dunia industry artinya; bukanteori semata. Obyeknya baik paten proses atau paten produk dan alat akan diproduks dalam jumlah besar dan diperjualbelikan, serta haknya dapat dialihkan ke dunia bisnis melalui perjanjian lisensi, atau yang lain.
\end{abstract}

Sistem Pendaftaran Paten Ada dua (2) system pendaftaran paten, yaitu:

a. Sistem first to file adalah suatu system yang memberikan hak paten bagi mereka yang mendaftar pertama atas invensi baru sesuai dengan persyaratan.

b. Sistem first to invent adalah suatu system yang memberikan hak paten bagi mereka yang menemukan inovasi pertama kali sesuai dengan persyaratan yang telah ditentukan. Dokumen-dokumen yang diperlukan untuk pendaftaran permohonan paten adalah sebagai berikut: a. Formulir yang telah diisi. b. Spesifikasi permohonan paten: 3 rangkap.

c. Surat kuasa, jika diajukan melalui kuasa hokum. d. Surat pernyataan untuk diberi paten. Hal-hal Dihindari Sebelum Mengajukan Paten Yang harus dihindari sebelum permintaan paten diajukan adalah pengungkapan atau mempublikasikan secara umum hasil penelitian atau penemuan dalam jangka waktu 6 (enam) bulan sebelum permintaan paten diajukan. Pengugkapan suatu hasil penelitian atau penemuan dapat terjadi dalam 3 cara: a. Melalui penguraian teknik dengan tulisa yang dipublikasikan. b. Melalui penguraian produk dan atau cara penggunanya di depan umum. c. Melalui pameran produk, dapat berupa suatu pameran internasional atau nasional di Indonesia atau di luar 
negeri yang resmi atau diakui sebagai resmi.

Yang Harus Dilakukan Sebelum Mengajukan Paten a. Melakukan penelususran (searching) informasi paten di beberapa website, antara lain: b. Melakukan analisa, dan men-cheek apakah ada cirri khusus dari invensi yang akan diajukan untuk mendapat perlindungan hak paten dibandingkan dengan invensi terdahulu, yang masih berlaku hak patennya.

\section{ACKNOWLEDGEMENT}

University Of Indonesia

University Of Mitra Indonesia

Telkom University

University Of Mellbourne

Saitama University.

\section{REFERENCE(Based ISO} 690 )

[1]
A. S. Putra And O. M. Febriani, "Knowledge Management Online Application In Pdam Lampung Province,” In
Prosiding International

Conference On Information

Technology And Business

(Icitb), 2018, Pp. 181-187.

[2] A. S. Putra, O. M. Febriani, And B. Bachry, "Implementasi Genetic Fuzzy System Untuk Mengidentifikasi Hasil Curian Kendaraan Bermotor Di Polda Lampung," J. Sist. Inf. Dan Manaj. Basis Data, Vol. 1, No. 1, Pp. 21-30, 2018.

[3] O. M. Febriani And A. S. Putra, "Sistem Informasi Monitoring Inventori Barang Pada Balai Riset Standardisasi Industri Bandar Lampung," J. Inform., Vol. 13, No. 1, Pp. 90-98, 2014.

[4] Putra, Arie Setya. "2018 Artikel Struktur Data, Audit Dan Jaringan Komputer." (2018).

[5] Putra, A. S. (2018, July 17). Paperplain Fundamental Create Application With Borland Delphi 7.0 University Of Mitra Indonesia. Retrieved From Osf.Io/Pbrn9. 
Jaringan Sensor Nirkabel. IJEIS

(Indonesian Journal of Electronics and

Instrumentation Systems), 8(2), 221-

232.

\section{E. REFERENCE(Based APA )}

Putra, A. S., Aryanti, D. R., \& Hartati,

I. (2018, November). Metode SAW

(Simple Additive Weighting) sebagai

Sistem Pendukung Keputusan Guru

Berprestasi (Studi Kasus: SMK Global

Surya). In Prosiding Seminar Nasional

Darmajaya (Vol. 1, No. 1, pp. 85-97).

Sari, D. P., Febriani, O. M., \& Putra,

A. S. (2018, November). Perancangan

Sistem Informasi SDM Berprestasi

pada SD Global Surya. In Prosiding

Seminar Nasional Darmajaya (Vol. 1,

No. 1, pp. 289-294).

Putra, A. S. (2018). Paperplain:

Execution Fundamental Create

Application With Borland Delphi 7.0

University Of Mitra Indonesia.

Putra, A. S., Sukri, H., \& Zuhri, K.

Sistem Monitoring Realtime Jaringan

Irigasi Desa (JIDES) Dengan Konsep
Darmawan, A., Yuliawati, D., Marcella, O., \& Firmandala, R. (2016). Sistem Absensi dan Pelaporan Berbasis Fingerprint dan SMS Gateway. EXPLORE, 7(1).

Febriani, O. M., Wahyuni, T., \& Yusuf, S. (2017). DESIGN OF WEBSITE-BASED INFORMATION SYSTEM FOR EDOCUMENT ADMINISTRASI IN THE COMMUNITY SERVICE UNIT (A Case Study at Rajabasa District). INTERNATIONAL JOURNAL OF COMPUTERS \& TECHNOLOGY, 16(7), 7010-7020.

Febriani, O. M., \& Wahyuni, T. (2017, October). PERANCANGAN SISTEM E-DOCUMENT ADMINISTRASI LOGBOOK PENELITIAN PADA UNIT LAYANAN DI BANDAR LAMPUNG. In Prosiding Seminar Nasional Darmajaya (Vol. 1, No. 1, pp. 187-194). 
Febriani, O. M., \& Permadi, A. B. (2017). Implementasi Sistem Aplikasi

Data Bimbingan dan Pelanggaran Siswa pada Sekolah Menengah Atas di Lampung Tengah dengan Metode Analisis dan Desain Sistem Terdistribusi (SSAD). EXPERT, 7(1).

Febriani, O. M., \& Ambarwati, L. (2015). PERANCANGAN APLIKASI PENGOLAHAN DATA PENJUALAN UKM KELANTING KHAS TELO DESA SIDOHARJO KECAMATAN JATI AGUNG KABUPATEN LAMPUNG SELATAN. Jurnal Teknologi Informasi dan Bisnis Pengabdian Masyarakat Darmajaya, 1(1), 77-95.

Febriani, O. M. (2015). Rancang Bangun Aplikasi Ecommercemenggunakan Freewebstore pada UKM Kelanting di Desa Sidoharjo Lampung Selatan. Prosiding Sembistek 2014, 1(02), 446-458. 